\title{
IAMJ
}

INTERNATIONAL

AYURVEDIC

MEDICAL JOURNAL

\section{ROLE OF KARPASABEEJA CHURNA IN THE TREATMENT OF STANYAKSHAYA - A PILOT STUDY}

\section{Rajni Kanojiya ${ }^{1}, \underline{\text { Shreves. }}^{\mathbf{2}}, \underline{\text { Yogitha Bali M.R }}^{3}$}

${ }^{1}$ PG Scholar, ${ }^{2}$ Associate Professor; Dept of Prasooti Tantra \& Stree Roga, Rajiv Gandhi Education Society's Ayurvedic Medical College, Ron, Karnataka, India

${ }^{3}$ Professor and HOD, Dept of Shareera Rachana, Sushrutha Ayurvedic Medical College, Bangalore, Karnataka, India; Ayurveda \& Yoga Consultant, AAYUSH- Multispeciality Ayurveda \& Integrated Healthcare, Bangalore, Karnataka, India

Corresponding Author: shrss02@gmail.com

https://doi.org/10.46607/iamj0208092020

(Published online: September 2020)

Open Access

(C) International Ayurvedic Medical Journal, India 2020

Article Received:16/07/2020 - Peer Reviewed: 27/08/2020 - Accepted for Publication: 27/08/2020

\section{(D) Check for updates}

\section{ABSTRACT}

Background: Stanyakshaya is the common problem noticed in about $40 \%$ patients in our clinical practice. Due to adaptation of Western culture, women get exposed to stress and strain. Lactation is the process associated with psychosomatic condition and lifestyle. Breast milk is the perfect food for a normal neonate. It is the best gift a mother can give her baby. Breast feeding is the ideal form of infant feeding and is crucial for lifelong health and wellbeing.

Design: This was a single pilot study. 10 patients(lactating mothers, both primi and multi gravida) who fulfilled the eligibility criteria were selected for the study and the assessments were made before the treatment on the $1^{\text {st }}$ day and after the treatment on the $30^{\text {th }}$ day and follow up was done on $20^{\text {th }}$ day after the completion of treatment.

Intervention: Karpasabeejachurna (6gms) was administered with lukewarm water as the Anupana after food twice a day for one month and follow up carried out on 20th day after the completion of treatment.

Results: Karpasabeejachurna showed statistically significant results in the Stanamlanata, Stana/milk ejection, breast feeding, weight of the baby and breast engorgement with $\mathrm{p}<0.001$. 
Conclusion: Karpasabeejachoorna showed to be effective in increasing the Stanya and it is a Stanyajanakadravya.

Keywords: Stanyajanana, Karpasabeeja Churna, Stanyakshaya, Breast milk.

\section{INTRODUCTION}

Breast milk is like nectar to the child, which gives many benefits to both mother and child. Ayurveda Classics has praised the breast milk very much and proposed the exclusive breast feeding up to 6 months and continuation up to $1 \mathrm{yr}$ or more. The WHO recommends exclusive breastfeeding for the first six months of life, after which "infants should receive nutritionally adequate and safe complementary foods while breast feeding continues for up to two years of age or beyond. ${ }^{[1]}$ The AAP recommends exclusive breast feeding for the first six months of life. ${ }^{[2]}$ Furthermore breast feeding should be continued for at least the first year of life and beyond for as long as mutually desired by mother and child. Due to the adaptation of western lifestyle and more expose towards stress and strain, the women face many problems. Amongst these, Stanyakshaya is a major problem, which seems to be very simple condition but pertaining to children's health it is a major problem. In Asian \& Tropical countries like India prevalence of lactational deficiency may be $30-40 \%{ }^{[3]}$ Breast feeding promotes physical and emotional bonding between the mother and child leading to better parent-child adjustment. Stanyaksaya is a vital problem with increasing prevalence, ranging from $23-63 \%$ in western countries and $45-53 \%$ in some part of India. ${ }^{[4]}$ It is a great irony that such an important problem that is directly associated with the health of the mother and child is largely neglected. Complications of Stanyakshaya are exhaustion, stress, PCOS, CA of breast, hypothyroidisum, Weight Loss, Obesity, Infection, No Milk for Baby, and Hormonal Imbalance. Drug use during pregnancy and lactation is an almost inevitable event. Some of the drugs may have adverse effects on the baby on exposure. It is therefore necessary for the physician to be aware of the changes in pharmacokinetics and pharmacodynamics during pregnancy. Knowledge about the known teratogens and drugs safe to be used during pregnancy is essential on the part of the prescribing physician. There are many factors affecting drug passage into the milk and thus affecting the child in some cases. We also find some drugs affecting lactation. No specific effective and safe treatment has been proposed so far in conventional system of medicine. Ayurveda is the oldest ancient system of Indian Medicine practiced since 5000yrs. As Ayurvedic drugs have no side effects, can be safe for both baby and the mother. In this science, Ayurveda, we can find a large number of the drugs, diet, and behavior regimen which are described to be as Stanyajanana and useful in the management of Stanyakshaya, but no scientific studies are available to validate this. In the view of the above, present study was designed to evaluate the Stanyajanana effect of the Ayurvedic drug prescribed in the Ayurveda classics. The drug named Karpasabeeja Churna proposed by Yogaratnakara ${ }^{[5]}$ was used in this study to evaluate the effect of its Stanyajanana property.

\section{Methodology}

This was a single pilot study. 10 patients (lactating mothers, both primi and multi gravida) aged between 18 to $35 \mathrm{yrs}$ with the features of Stanyakshaya and who fulfilled the eligibility criteria were selected for the study from OPD and IPD of Prasooti Tantra and Stree Roga Department of Rajiv Gandhi Education Society's Ayurvedic Medical College Ron, Karnataka. Patients with the features of Stanyakshaya and from the $5^{\text {th }}$ day of delivery were included for the study. Mothers with pathologies like engorgement, cracked or sore nipples, mastitis, flat/inverted nipples, history of breast abscess, or any systemic diseases that may interfere with the course of treatment were excluded from the study. Informed consent was obtained from all the patients and ethical clearance was obtained from the institutional review board. Assessments were made before the treatment on the $1^{\text {st }}$ day and after the 
treatment on the $30^{\text {th }}$ day and follow up was done on $20^{\text {th }}$ day after the completion of treatment. Investigations like Haemoglobin \% ( $\mathrm{Hb} \%)$, Fasting blood sugar (FBS) and Serum Prolactin were also carried out.

Intervention In this study, all the 10 patients were given Karpasabeeja Churna in the dose of 6gms, with lukewarm water as the Anupana after food twice a day for 30 days with instructions given on Pathya Ahara and vihara to be followed. The medicine Karpasabeeja Churna was prepared by collecting the raw drugs from the Ayurvedic pharmacy under the supervision of Dravya Guna and the Rasashastra department at Rasashala attached to college. The ingredients mentioned in formulations were taken and clean then dried properly. After drying, the entire ingredient was powdered separately and then sieved to use.

\section{Outcome measures:}

a) Subjective Parameters: Stanamlanata and Milk Ejection

b) Objective Parameters: Baby weight, Breast feeding frequency, Breast engorgement

Table 1: Assessment Criteria

\begin{tabular}{|c|c|c|c|}
\hline Sl.No & Parameters & Lakshanas & Grading \\
\hline \multirow[t]{4}{*}{1.} & Stanamlanata & Shushkatwa, Stanya Alpata, Stanya Asambhava & 3 \\
\hline & & $\begin{array}{l}\text { Shushkatwa, Stanya Alpatal Shushkatwa, Stanya Asambhava/ Stanya Alpata, } \\
\text { Stanya Asambhava }\end{array}$ & 2 \\
\hline & & Stanya Asambhava/Shushkatwa/Stanya Alpata & 1 \\
\hline & & None & 0 \\
\hline \multirow[t]{4}{*}{2.} & Milk Ejection & Forceful & 3 \\
\hline & & Streamlike & 2 \\
\hline & & Drop by Drop & 1 \\
\hline & & No Ejection & 0 \\
\hline \multirow[t]{4}{*}{3.} & Baby weight & Sharir bhar vruddhi (record on every 15 days) & 3 \\
\hline & & Aruddhi (no weight gain) & 2 \\
\hline & & Alpa (100 to 175 gms per week) & 1 \\
\hline & & Adhika or Prakrut (above 175 gms per week) & 0 \\
\hline \multirow[t]{3}{*}{4.} & $\begin{array}{l}\text { Cry for demand } \\
\text { (Rodan) }\end{array}$ & Adhik - Demand feeds before every 2 hrs. & 2 \\
\hline & & Alpa -Demand feeds after every $2-3 \mathrm{hrs}$ & 1 \\
\hline & & Prakrut-Demand feeds after every $3-4 \mathrm{hrs}$ & 0 \\
\hline \multirow[t]{4}{*}{5.} & $\begin{array}{l}\text { Breast feeding fre- } \\
\text { quency }\end{array}$ & Feeding $0-2$ times/ day & 3 \\
\hline & & Feeding 3-5 times/day & 2 \\
\hline & & Feeding 6-8 times/day & 1 \\
\hline & & Feeding 9-12 times/day & 0 \\
\hline \multirow[t]{4}{*}{6.} & Breast engorgement & Prakrut- No engorgement & 0 \\
\hline & & Alpa-Slight engorgement & 1 \\
\hline & & Madhyam- Moderate engorgement, no Vednahara Aushadhi required & 2 \\
\hline & & Adhik- Severe pain Vedanahar Aushadhi required & 3 \\
\hline
\end{tabular}


Data Extraction and Analysis: The data obtained was recorded, tabulated and statistically analyzed using appropriate statistical methods.

\section{Results}

Table 2: Demographic data

\begin{tabular}{|l|l|l|}
\hline Age & $18-23$ yrs & 4 \\
\hline & $24-29 y r s$ & 2 \\
\hline Primi/multi & $30-35$ yrs & 4 \\
\hline & Primi gravida & 4 \\
\hline Education & Multi gravida & 6 \\
\hline & Educated & 6 \\
\hline Occupation & Uneducated & 4 \\
\hline & Housewives & 6 \\
\hline Economic background & In service & 3 \\
\hline & Labourer & 1 \\
\hline & Lower & 2 \\
\hline Religion & Middle & 5 \\
\hline & High & 3 \\
\hline Diet & Hindus & 6 \\
\hline & Muslims & 3 \\
\hline & Christians & 1 \\
\hline & Veg & 4 \\
\hline
\end{tabular}

\section{Subjective Parameters}

1. Stanamlanata: The initial mean of stanamlanata was 3 and reduced to 1.23 at the end of $30^{\text {th }}$ day which showed statistically significant results with $\mathrm{p}<0.001$.

2. Stanya/Milk ejection: The initial mean of the Stanya/milk ejection was 2.76 and was reduced to 1 at the end of $30^{\text {th }}$ day which showed statistically significant results with $\mathrm{p}<0.001$.

3. Weight of the Baby: The initial mean of weight of the baby was 2.76 and was reduced to 1 at the end of $30^{\text {th }}$ day which showed statistically significant results with $\mathrm{p}<0.001$.

4. Breast feeding: The initial mean of breast feeding was 2.76 and was reduced to 1 at the end of $30^{\text {th }}$ day which showed statistically significant results with $\mathrm{p}<0.001$.

5. Breast engorgement: The initial mean of the breast engorgement was 2 and this was reduced to 1.07 at the end of $30^{\text {th }}$ day which showed statistically significant results at $\mathrm{p}<0.001$.

Table 3: Results Before and After Treatment

\begin{tabular}{|l|l|l|l|l|l|l|l|l|}
\hline \multirow{2}{*}{ Sl. No. } & Parameters & \multicolumn{2}{|l|}{ Mean Score } & \% Improvement & SD & SE & T & P \\
\cline { 3 - 10 } & & BT & AT & & & & & \\
\hline 1 & Stanamlanata & 3 & 1.23 & 58.97 & 0.429 & 0.084 & 20.99 & $<0.001$ \\
\hline 2 & Stanya Ejection & 2.76 & 1 & 63.88 & 0.429 & 0.084 & 20.99 & $<0.001$ \\
\hline 3 & Breast Feeding & 2.76 & 1 & 63.88 & 0.429 & 0.084 & 20.99 & $<0.001$ \\
\hline 4 & Weight of the Baby & 2.76 & 1 & 63.88 & 0.429 & 0.084 & 20.99 & $<0.001$ \\
\hline 5 & Breast Engorgement & 2 & 1.07 & 46.15 & 0.39 & 0.076 & 12 & $<0.001$ \\
\hline
\end{tabular}


Follow up Results: The follow up was done on the $20^{\text {th }}$ day after the completion of treatment in which the premean of Stanamlanata which was 3 got reduced to 0.96 with statistically significant results $(\mathrm{p}<0.001)$ on the $20^{\text {th }}$ day after the completion of treatment. The pre mean of Stanya/milk ejection was 2.9 and was reduced to 0.57 with statistically significant results $(\mathrm{p}$ $<0.001)$. Breast feeding got reduced from 2.9 to 1 with $\mathrm{p}<0.001$, Weight of the baby with the premean 2.92 got reduced to 0.57 with $\mathrm{p}<0.001$ and the breast engorgement with pre mean of 1.92 was reduced to 0.96 with $\mathrm{p}<0.001$ on the $20^{\text {th }}$ day after the completion of treatment.

\section{DISCUSSION}

According to Charaka, the excellent milk has normal colour, smell, taste and touch. Dissolves completely in water if milk in a water pot because of its (watery) nature. Such milk is nourishing and health giving. Thus, is the excellence of breast milk ${ }^{[6]}$. Whereas as per Sushrutha, the breast-milk, which put in water becomes one with it, is pale, sweet and free from abnormal colour, and should be known as normal ${ }^{[7]}$. Kashyapa without mentioning any physical characters says that the pure milk is that which provides unobstructed, easy and good growth of strength, different body parts, longevity as well as good health too the child and does not cause any pain or trouble to the child and wet-nurse ${ }^{[8]}$.

Not all the properties of breast milk are understood, but its nutrient content is relatively stable. Breast milk is made from nutrients in the mother's blood stream and bodily stores. Breast milk has just the right amount of fat, sugar, water, and protein that is needed for a baby's growth and development ${ }^{[9]}$. Because breastfeeding uses an average of 500 calories a day it helps the mother lose weight after giving birth ${ }^{[10]}$. In the present study, among the 10 patients included for the study, 4 patients were in the age group of 18 23yrs, 2 patients aged between 24-29yrs and 4 patients were in the age group of 30-35yrs, 4 patients were primi and 6 multi gravid females, 6 patients were educated and 4 were uneducated, among them, 6 patients were housewives, 3 were in service and 1 was a la- bourer. 5 of them fall under middle economic background, 3 high and 2 lower economic backgrounds. 7 patients were from urban and 3 were from rural area. 6 patients were Hindus, 1 Christian and 3 Muslims. 4 patients were vegetarians and 6 were of mixed diet. With pre and post-test design single pilot study conducted on 10 patients with complaints of stanyakshaya during puerperal period, patients were given Karpasabeeja Churna of 6gms was administered with luke warm water twice a day after food for 30 days with instructions of Pathya Ahara and vihara to be followed. All the selected patients were thoroughly examined, diagnosed and included for the study based on the inclusion and exclusion criteria. As this was a pre-post design, after treatment results showed that the pre mean of Stanamlanata which was 3, reduced to 1.23 at the end of 30th day with statistically significant results $\mathrm{p}<0.001$. Pre mean of Stanya /milk ejection reduced from 2.76 to 1 with statistically significant results with $\mathrm{p}<0.001$. Breast feeding reduced from 2.76 to 1 with $p<0.001$. Weight of the Baby came down from 2.76 to 1 with $p<0.001$ and breast engorgement showed statistically significant results with pre mean reduced from 2 to 1.07 the end of 30th day with $\mathrm{p}<0.001$. Karpasabeeja Churna explained by Yogarathnakara has been used for the present study as the drug is known to inherently possess the Stanya Janana Property. Apart from the classical reference of the drug possessing Stanyajanana Karma, the Samanyata between the drug and the Stanya is established based on the similarities the above two share Apya Dravya, Madhura Rasa, Shita, Snigdha, Pichhila Guna with Santarpana and Balya properties. The objective of the study was to assess the Stanya Janana action of the drug Karpasabeeja based on the principle of Samanya Siddhanta. Here the drug Karpasabeeja is taken as Karana and the Stanya Vriddhi as the Karya. As the Vriddhi of the Karya is intended in this study, the Samanya Siddhanta is applied in relation to the Karya i.e., Samanya causes Vriddhi, thus the Vriddhi of Stanya is ascertained under the domains of Dravya, Guna and Karma. Acharya Charaka illustrates the fifty Mahakashaya i.e., 50 important varieties of decoctions. Each Kashaya Varga consists of 10 
drugs each. The ten drugs termed as Dashemani are grouped as they are oriented to a particular target action either leading to an increase or its palliation. Based on the Samanya principle of Ayurveda, increase is caused by the use of similar substances. Thus, one such drug from a desired group is chosen to study the principle of Samanya through a clinical interventional study. The Kashaya Varga chosen for the present study is the Stanyajanana Kashaya Varga and the drug chosen is Karpasabeeja Chourna as the Samanya is applied with regard to its three bhava or domains namely Dravya Samanya, Guna Samanya and Karma Samanya, in which the present study also includes the study of the Samanya under the above 3 domains.

Mode of Action: The probable mode of action is discussed in relation to its effect on the three domains,

Dravya This domain constitutes the quantitative increase of the Stanya. The increase in Stanya is attributed to the increase of the rasa dhatu which consequently leads to the increase of Stanya which is the Upadhatu of the rasa dhatu. Considering the Panchaboutika composition of the two, the drug is said to grow only in marshy lands by which it can be substantiated that it is an Apya Dravya. On the other hand, the Stanya is also an Apya Amsha that is produced in the body. Thus, on the grounds of pharmacodynamics, both the drug and the Stanya can be considered as Apya Dravya and hence the cause for its increase is attributed to the similarity in the Panchabautika composition between the two. Sapta Dhatu Poshaka property of the drug: As the rasa does the Poshana of all the other dhatus there by this fact reveals the direct increase on the rasa dhatu and thereby Stanya as the latter is Upa Dhatu of the former. Ruchya property of the drug: this leads to adequate consumption of the Ahara. This in turn results in the adequate production of the rasa thus contributing in the formation of Stan$y a$. Guna This domain constitutes the qualitative improvement of the Stanya. On the grounds of pharmacodynamics, this is affected by the similar properties of the drug with that of the Stanya like Madhura Rasa, Snigdha, Picchila Guna, Sheeta Virya. In addition, the Vatahara property of the drug has caused the disap- pearances of the vata vriddhi lakshanas like floating in water. In addition to the above-mentioned qualities, the properties like Santarpana, Balya of the drug may also have affected the corresponding components of the breast milk and thereby causing a significant change especially in the solid not fat constituent of the breast milk. The SNF consists of proteins, lactose and other micronutrients. They perform a variety of functions in living organisms ranging from providing structure to reproduction. Thus, from this explanation a relation can be drawn between the properties of the protein constituents of the breast milk and those with that of the drug like Dhatu Vardhana, Balya. The relation can also be drawn between the protein content and the breast milk proper. The breast milk is said to possess qualities like Shareera Upachaya, Balya, Ayushya, Dhatu Vardhana, Jeevana and Shishu Anapattihi. As discussed, these properties seem to correspond with the properties of the proteins as well. Hence an overall improvement in the quality of the milk can also be appreciated for its role in increasing the SNF concentration. Karma This domain constitutes the improvement in the activities of the infant as a consequence of qualitative improvement in the Stan$y a$. This can be attributed to the quantitative increase in the breast feeds and there by the Stanya leading to the Apyayana or nourishment in the infant there by leading to an increased weight. The adequacy achieved in the breast feeding is thus consequently able to improve the frequency of the urine and the stool output of the infant suggesting an adequate intake influencing on the adequacy in the elimination pattern. On the other hand, the qualitative improvement in the breast milk with regards to the Upa Snehana property along with the Snigdha and Picchila Guna may have a role in leading to easy and regular evacuation of the stools. The Upakleda property on the other hand may play a role in frequency of the urine output. The Nidrakara property may play a role in increasing the duration of sleep. 


\section{CONCLUSION}

Karpasabeeja Churna Showed statistically significant results in the Stanamlanata, Stana/milk ejection, breast feeding, weight of the baby and breast engorgement with $\mathrm{p}<0.001$. Thus, Karpasabeeja Choor$n a$ showed to be effective in increasing the Stanya and it is a Stanyajanaka Dravya.

\section{REFERENCES}

1. Infant and young child feeding fact sheet No 342.WHO Feb. 2014.

2. American Academy of Pediatrics Section on Breastfeeding. (March 2012). "Breastfeeding and the use of human milk". Pediatrics. 129 (3): e827-41. doi:10.1542/peds.2011-3552. PMID 22371471.

3. Dr. Ankit Agrawal, Dr. Deepika Mehra, Dr. Sujit Kumar, Dr. Mariya Husain, Dr. Vaidehi V Raole and Dr. Sunil P Nikhate. A conceptual study on Stanya: An ayurvedic review The Pharma Innovation Journal 2019; 8(5): 118-122.

4. Kiran Tanwar, Uma Shankar Sharma, Ankur Kumar Tanwar. To evaluate the efficacy of Aahara-Vihara on Stanya Kshaya in Healthy Female Volunteers of different Deha Prakriti. J Ayurveda Integr Med Sci 2016;1(1):1-6.

5. Vaidya Sreelakshmipatishastri Commentator, Brahma shankarashastr Editor, Yogarathnakara. Choukhambha prakashana. Varanasi. Reprint: 2003, pp;416-431.

6. Acharya YT, Charaka Samhita of Agnivesha, 5th Ed, Varanasi, Choukhambha Prakashana, 2007, 376 Vrunda Madhava. 880.

7. Acharya YT, Acharya NR. Sushruta Samhita of Sushruta. 7th ed., Varanasi: Chowkamba Orientalia, 2003, 499 .

8. Vriddha Jeevaka.Kashyapa samhitha.Text with English Translationand commentary by P.V.Tewari. Chaukhambha Vishvabharati.Varanasi. $1^{\text {st }}$ Edition.1996.

9. Kramer M, Kakuma R (2002). "Optimal duration of exclusive breastfeeding". Cochrane Database Syst Rev (1): CD003517. doi:10.1002/14651858.CD003517. PMID 11869667.

10. Baker R (2003). "Human milk substitutes. An American perspective". Minerva Pediatr 55 (3): 195-207.

\section{Source of Support: Nil \\ Conflict of Interest: None Declared}

How to cite this URL: Shreyes. S et al: Role Of Karpasabeeja Churna In The Treatment Of Stanyakshaya - A Pilot Study. International Ayurvedic Medical Journal \{online\} 2020 \{cited September, 2020$\}$ Available from: http://www.iamj.in/posts/images/upload/4310 4316.pdf 